\title{
Strategi Pelayanan Guru Sekolah Minggu Bagi Pertumbuhan Rohani Anak
}

\author{
Mikha Agus Widiyanto \\ Sekolah Tinggi Teologi Tenggarong \\ Email:mikha.agus08@gmail.com \\ Nostry \\ Sekolah Tinggi Teologi Tenggarong \\ Email:nostri.sttt16@gmail.com
}

\begin{abstract}
Sunday school teachers have an important role in the children's spiritual formation. Through the right ministry strategy, children could be guided to grow in their spiritual life. This study aimed to examine the effective Sunday school teacher service strategies in increasing the children's spiritual growth. The method used in this research was correlational. The research was conducted at the Indonesian Gospel Kemah Church, Kombeng District and Telen District, East Kutai District. The results showed that the Sunday school teacher service strategy had a significant effect on children's spiritual growth. Through child-centered learning and teaching creatively the Word of God have an impact on children's spiritual growth and improvement.
\end{abstract}

Keywords: Ministry Strategies; Spirtual Growth; Sunday School Teacher

\begin{abstract}
Abstrak
Guru sekolah minggu memiliki peran yang penting dalam pembinaan rohani anak. Melalui strategi pelayanan yang tepat, anak-anak akan dapat dibimbing bertumbuh dalam kehidupan rohaninya. Penelitian ini bertujua untuk menguji strategi pelayanan guru sekolah minggu yang efektif dalam meningkatkan pertumbuhan rohani anak. Metode yang digunakan dalam penelitian, yaitu korelasional. Penelitian dilaksanakan di Gereja Kemah Injil Indonesia Kecamatan Kombeng dan Kecamatan Telen, Kabupaten Kutai Timur. Hasil penelitian menunjukkan bahwa strategi pelayanan guru sekolah minggu berpengaruh secara signifikan terhadap pertumbuhan rohani anak. Melalui pembelajaran yang berpusat kepada anak dan mengajarkan Firman Tuhan secara kreatif berdampak bagi peningkatan dan pertumbuhan rohani anak.
\end{abstract}

Kata-kata Kunci: Strategi Pelayanan; Pertumbuhan Rohani; Guru Sekolah Minggu

\section{PENDAHULUAN}

Sekolah minggu sebagai salah satu unit pelayanan kategorial gereja yang menjadi sarana dalam pembinaan iman bagi anak-anak. Melalui sekolah minggu, anakanak dibimbing, dituntun, diajar dan dididik mengenai pokok-pokok iman Kristen, agar memiliki pondasi iman yang 
kokoh sejak dini. Pelayanan sekolah minggu merupakan pelayanan yang paling mendasar dalam memperkenalkan Yesus Kristus sebagai Tuhan dan Juruselamat bagi anak-anak. Melalui pelayanan ini anak-anak dapat mengenal Tuhan yang mengasihinya dan bertumbuh dalam kehidupan rohaninya. Gereja harus sedini mungkin membina anak-anak untuk mengenalkan Yesus Kristus sebagai Juruselamat melalui pelayanan Sekolah Minggu (Setiawani, 2000).

Anak-anak merupakan generasi penerus yang akan menerima tongkat estafet kepemimpinan gereja di masa yang akan datang. Melalui pembinaan dan pengajaran di sekolah minggu, gereja mempersiapakan generasi penerus bagi pemimpin masa depan dan pengembangan pelayanan gereja (Kristiono \& Perdana, 2019). Melalui pelayanan sekolah minggu, dipersiapkan generasi yang mengenal Tuhan dan bertumbuh dalam iman percaya yang kokoh hanya pada Yesus Kristus. Mengabaikan pelayanan anak berarti akan menghentikan proses pertumbuhan iman anak itu sendiri. Anak-anak sebagai harapan bagi gereja di masa yang akan datang (Juanda, 2016).

Terkait dengan tugas gereja tersebut, guru sekolah minggu sebagai pelayan anak-anak memegang peranan yang penting untuk mempersiapkan generasi penerus bagi pertumbuhan dan perkembangan gereja. Tanpa guru sekolah minggu, kemungkinan gereja akan mengalami kesulitan dalam melakukan regenerasi pertumbuhan gereja secara alamiah. Guru sekolah minggu melalui tugas mengajarnya, diharapkan mampu membimbing dan menuntun anak-anak untuk bertumbuh di dalam Yesus Kristus (Riniwati, 2020). Namun demikian, tidak semua gereja memberikan perhatiannya pada tugas ini dengan mempersiapkan guru Sekolah Minggu yang berkualitas, kreatif dan inovatif, sehingga dalam pelaksanaan tugasnya akan berdampak pada pertumbuhan rohani anak (Christiani, 2003; Riniwati, 2020; Nelly, 2019).

Mewujudkan pertumbuhan rohani bagi anak sekolah minggu, diperlukan strategi pelayanan yang tepat. Guru tidak hanya sekedar mentransferkan pengatahuan (knowledge) dalam pelaksanaan tugas mengajarnya, melainkan anak-anak dibimbing untuk mampu menampilkan perilaku sebagai murid Kristus. Untuk itulah diperlukan upaya yang terencana oleh guru sekolah minggu, sehingga tujuan yang ingin dicapai dalam pembelajaran sekolah minggu dapat tercapai (Sidjabat, 2017). Tercapainya tujuan tersebut yang tercermin melalui pertumbuhan rohani yang ditampilkan dalam perilaku anakanak.

Secara khusus di era revolusi industri 4.0, guru sekolah minggu 
menghadapai tantangan dalam memberikan bimbingan dan tuntunan kepada anak-anak melalui tugas mengajar dan mendidik. Guru termasuk dalam konteks pelayanan sekolah minggu dituntut memiliki skill, mental dan kapabilitas yang unggul dan memadai (Retnaningsih, 2019). Tuntutan bagi guru untuk dapat mengajar secara kreatif dan mendesain ibadah sekolah minggu yang sesuai dengan perkembangan teknologi dan informasi. Perkembangan teknologi yang membuat anak lebih tertarik dengan smartphone dengan berbagai aplikasi serta pilihan program yang dianggapnya lebih menarik. Melalui program-program yang bisa diakses melalui smartphone anak-anak diperhadapkan pada banyak pilihan. Secara khusus anak-anak yang lebih menyukai tayangan media benda gerak dengan berbagai kombinasi gambar yang menarik, tayangan video, film animasi dan sebagainya. Begitu juga dengan programprogram televisi yang bagi anak bisa saja dinilai lebih menarik, sehingga menjadi tantangan bagi guru sekolah minggu untuk bisa memberikan daya tarik kepada anak dalam pelayanannya melalui ibadah sekolah minggu (Panuntun, Tanduklangi, Adeng, \& Randalele, 2019).

Menurut Lie, (2003) Laufer dan Dyck (1997) bahwa guru sekolah minggu dalam pelaksanaan tugas mengajarnya, sudah semestinya memahami keinginan dan kebutuhan anak, sehingga seluruh kegiatan pengajaran dirancang yang berpusat kepada anak. Kebutuhan anak secara khusus dalam menghadapi tantangan di era digital, guru harus mampu menyesuaikan diri dengan perkembangan dan kebutuhan anak, sehingga mampu menyajikan materi pengajaran secara menarik dan inovatif. Membuat anak menyukai ibadah sekolah minggu dan menunjukkan intens dalam kehadirannya di ibadah.

Bermain merupakan dunianya bagi anak-anak. Pelayanan sekolah minggu dirancang yang disertai dengan berbagai permainan tanpa menghilangkan esensi dari ibadah dan pengajaran dalam memperkenalkan Tuhan Yesus sebagai Juruselamat bagi anak-anak. Bermain sebagai sarana dan strategi dalam menarik untuk anak-anak bisa mengikuti, dan mendengarkan pengajaran sehingga proses pembelajaran di sekolah minggu dapat berlangsung secara efektif. Melalui bermain, anak-anak mudah menerima pengajaran dan mengikutinya dengan senang (Siswanto, 2006). Strategi pelayanan yang dikembangkan guru sekolah minggu harus mampu memberikan daya tarik bagi anak sehingga membuatnya senang ketika mengikuti ibadah. Seluruh rangkaian ibadah didisain secara menarik, baik itu cerita, pujian dan aktivitas-aktivitas lainnya (Lie, 1999). Dalam pujian tidak hanya sekedar anak-anak diajak bernyanyi 
dengan suara nyaring, melainkan didesain dengan berbagai aktivitas gerakan, kreasi sahut-sahutan, kreasi tepuk tangan, kreasi alat peraga dan sebagainya. Demikian juga dalam menyampaikan cerita Firman Tuhan. Materi pengajaran sekolah minggu bersumber dari Alkitab yang kemudian di narasikan dalam bentuk cerita kepada anakanak. Cerita yang disampaikan harus mampu disajikan secara menarik, dengan berbagai aktivitas, alat peraga, ilustrasi, cara penyajian atau menuturkan cerita, ekspresi yang menarik dan sebagainya (Kadarmanto, 2003; Lie, 1997). Melalui strategi pelayanan yang tepat dalam pelayanan sekolah minggu, anak diajar untuk mengenal Tuhan Yesus dan bertumbuh dalam kehidupan rohaninya (Laufer \& Dyck, 1997).

Gereja sudah semestinya memfasilitasi dalam pelayanan anak guna mewujudkan pertumbuhan rohaninya, melalui persekutuan dan pengajaran (Latif, 2018). Melalui persekutuan anak-anak akan disadarkan akan pentingnya Allah dan membawanya memiliki pengalaman spiritual. Kesadaran ini yang membuat anak menjadi rajin beribadah, rajin berdoa, membaca Firman Tuhan, mengucap syukur, mampu memberikan pengampunan, suka memberi dan berbagi, serta menampilkan perilaku yang menghormati orang tua (Purba, 2019; Jacobsen, 1997; Caram, 1996).
Diperlukan strategi pelayanan sekolah minggu yang tepat, agar anak-anak dapat bertumbuh dalam pondasi iman yang kuat, sehingga dalam tahapan pertumbuhan selanjutnya tetap percaya dan kuat imannya di dalam Kristus. Permasalahan dalam penelitian ini dirumuskan sebagai berikut: Pertama, bagaimanakah peranan strategi pelayanan guru sekolah minggu bagi pertumbuhan rohani anak? Kedua, bentuk strategi manakah yang paling dominan mempengaruhi pertumbuhan rohani anak? Penelitian ini bertujuan untuk menguji dan mengetahui peranan dan bentuk strategi pelayanan guru sekolah yang tepat dalam upaya peningkatan pertumbuhan rohani anak secara efektif.

\section{METODE PENELITIAN}

Penelitian ini menggunakan pendekatan kuantitatif dengan metode korelasional. Penelitian ini dilakukan di Gereja Kemah Injil Indonesia Kecamatan Kongbeng dan Telen Kabupaten Kutai Timur yang meliputi, Jemaat Miau Baru, Makmur Jaya, Marga Mulia, dan Rantau Panjang. Populasi penelitian ini adalah anak sekolah minggu yang berusia $11-12$ Tahun dengan jumlah sebanyak 138 anak. Sedangkan sampel penelitian ini sebanyak 50 orang anak sekolah minggu yang diambil dari populasi dengan menggunakan teknik simple random sampling. 
Instrumen penelitian ini meliputi terdiri dari instrument strategi pelayanan guru sekolah minggu dan pertumbuhan rohani. Instrumen penelitian dikembangkan dengan skala perilaku, baik dalam pernyataan posotif maupun negatif dengan lima pilihan jawaban, yaitu: Sangat Sesuai (SS), Sesuai (S), Kadang-kadang Sesuai (KS), Tidak Sesuai (TS) dan Sangat Tidak Sesuai (STS). Instrumen strategi pelayanan guru sekolah minggu dikembangkan dari Kadarmanto (2003), Lie (1999), dan Laufer \& Dyck (1997) yang diukur dengan indikator: 1) Model pembelajaran yang berpusat pada anak, 2) Pelayanan pujian yang kreatif, 3) Mengajarkan Firman Tuhan secara kreatif, 4) Mengajar dengan menggunakan alat peraga, 5) Ibadah Padang. Instrumen ini dikembangkan dengan butir pernyaataan sebanyak 15 butir pernyataan yang dinyatakan valid. Pengujian validitas dilakukan dengan uji content validity dengan face validity dan item validity yang dilakukan secara statistika melalui analisis Pearson Product Moment. (Widiyanto, 2014) Lima belas item yang valid kemudian dilakukan pengujian reliabilitas dengan pendekatan internal konsistensi. Instrumen strategi pelayanan sekolah minggu diperoleh koefisien reliabilitas sebesar 0,862 .

Instrumen pertumbuhan rohani anak dikembangkan dari Caram (1996), Jacobsen (1997) dan Griffiths (1991) yang diukur dengan indikator meliputi:1) Suka beribadah dan Suka berdoa, 2) Mudah mengampuni, 3) Suka memberi, 4) Selalu mengucap syukur kepada Tuhan, 5) Suka membaca Firman Tuhan. Instrumen pertumbuhan rohani terdiri dari 15 item yang valid dengan koefisien reliabilitasnya sebesar 0,837 .

Analisis data dilakukan dengan pengujian statistika yang meliputi statistika deskriptif dan statistika inferensial. Statistika deskriptif meliputi perhitungan skor minimum, skor maksimum, rata-rata dan standar deviasi. Sedangkan statistika inferensial melalui uji korelasi dan regresi sederhana. (Widiyanto, 2013) Kemudian dilakukan analisis Classification and Regression Tree strategi yang paling dominan mempengaruhi pertumbuhan rohani anak. Dalam analisis ini ditetapkan Prunning yaitu Depth 2; Parent sebesar 2; dan Child sebesar 1.

\section{HASIL DAN PEMBAHASAN}

Berdasarkan analisis data diperoleh hasil sebagai berikut: Dari 50 orang yang menjadi responden dalam penelitian ini, terdiri dari 16 anak atau sebesar 32\% yang berjenis kelamin laki-laki dan sebanyak 34 anak atau $68 \%$ yang berjenis perempuan. Dengan demikian, responden penelitian ini yang berjenis kelamin perempuan lebih banyak di bandingkan responden yang berjenis kelamin laki-laki. 
Dari analisis statistika deskriptif, diperoleh hasil sebagai berikut:

\begin{tabular}{|l|c|c|c|c|c|}
\hline \multicolumn{7}{|c|}{ Tabel 1. Deskripsi Data Variabel Penelitian } \\
\hline \multicolumn{1}{|c|}{ Variabel } & N & Minimum & Maximum & Mean & Std. Deviation \\
\hline $\begin{array}{l}\text { Strategi Pelayanan } \\
\text { Sekolah Minggu }\end{array}$ & 50 & 35 & 75 & 61.96 & 10.480 \\
\hline $\begin{array}{l}\text { Pertumbuhan Rohani } \\
\text { Anak }\end{array}$ & 50 & 41 & 75 & 61.06 & 10.464 \\
\hline
\end{tabular}

Hasil Output SPSS

Berdasarkan tabel 1 tentang deskripsi data, pada variabel strategi pelayanan guru sekolah minggu berdasarkan penilaian anak, diperoleh skor minimum sebesar 35 dan skor maksimum sebesar 75 dengan jumlah item instrument sebanyak 15, maka rata-rata sekor minimum 2,33 sedangkan skor rata-rata maksimum sebesar 5. Skor rata-rata dari keseluruhan 61,96 dari jumlah 15 item, maka setiap responden memiliki skor ratarata berkisar antara 4.11; Dengan rentang skor antara 1 - 5, maka skor 4.11 menunjukkan bahwa strategi pelayanan guru sekolah minggu telah baik karena sudah mendekati skor teoritis tertinggi.

Sedangkan pada pertumbuhan rohani anak sekolah minggu, diperoleh skor minimum sebesar 35 dan skor maksimum sebesar 75 dengan jumlah item instrument sebanyak 15, maka rata-rata sekor minimum 2,73 sedangkan skor rata-rata maksimum sebesar 5. Skor rata-rata dari keseluruhan 61,06 dari jumlah 15 item, maka setiap responden memiliki skor ratarata berkisar antara 4.07; Dengan rentang skor antara $1-5$, maka skor 4.07 menunjukkan bahwa pertumbuhan rohani anak sekolah minggu telah baik karena sudah mendekati skor teoritis tertinggi.

Berdasarkan nilai standar deviasi menunjukan bahwa strategi pelayanan guru sekolah minggu memiliki nilai yang lebih tinggi $(10,480)$ dibandingkan dengan pertumbuhan rohani anak $(10,464)$ yang memberikan gambaran bahwa penilain anak terhadap strategi pelayanan guru sekolah minggu lebih bervariasi. 
Hasil analisis statistika inferensial disajikan dalam tabel ringkasan berikut ini.

Tabel 2. Hasil Pengujian Hubungan Antara Variabel Penelitian

\begin{tabular}{|c|c|c|c|c|c|c|c|c|}
\hline $\begin{array}{c}\text { Hubungan } \\
\text { Antar Variabel }\end{array}$ & $\mathbf{a}$ & $\mathbf{b}$ & $\mathbf{r}$ & $\mathbf{r}^{2}$ & $\mathbf{F}$ & $\mathbf{t}$ & $\begin{array}{c}\boldsymbol{P} \text { - } \\
\text { alue }\end{array}$ & Hasil \\
\hline $\begin{array}{c}\text { Strategi } \\
\begin{array}{c}\text { Pelayanan Guru } \\
\text { Sekolah Minggu } \\
\text { Pertumbuhan } \\
\text { Rohani Anak }\end{array}\end{array}$ & 0.249 & 0.981 & 0.983 & 0.966 & 1377.476 & 37.114 & 0.000 & Signifikan \\
\hline \\
Hasil output SPSS
\end{tabular}

Hasil Output SPSS

Berdasarkan tabel 2, dari hasil penghitungan didapatkan koefisien $\mathrm{F}$ sebesar 1377.476 dengan $P$-value sebesar 0,00 lebih kecil dari 0,05 yang memiliki arti bahwa persamaan regresi $\hat{Y}=0,249+0,981$ $\mathrm{X}$ adalah signifikan. Hasil analisis regresi ini dapat digunakan untuk memprediksi bahwa apabila skor rata-rata strategi pelayanan guru sekolah minggu meningkat satu unit maka skor rata-rata pertumbuhan rohani anak akan meningkat sebesar 0,981 pada konstansa 0,249.

Besarnya koefisien strategi pelayanan bagi pertumbuhan rohani anak $r$ 0,983 dengan koefisien $\mathrm{t}$ sebesar 37,114 dan P-value sebesar 0,000 yang lebih kecil dari 0,05 menunjukkan bahwa terdapat pengaruh yang positif dan signifikan strategi pelayanan guru sekolah minggu terhadap pertumbuhan rohani anak di GKII Kecamatan Kongbeng dan Kecamatan
Telen, khusus di jemaat GKII Miau Baru, GKII Makmur Jaya, GKII Marga Mulia, dan GKII Rantau Panjang.

Berdasarkan nilai koefisien determinansi varians sebesar 0,966 menunjukkan bahwa strategi pelayanan sekolah minggu memberikan peranan sebesar 96,6\% dalam meningkatkan pertumbuhan rohani anak di GKII Kecamatan Kongbeng dan Kecamatan Telen, khusus di jemaat GKII Miau Baru, GKII Makmur Jaya, GKII Marga Mulia, dan GKII Rantau Panjang. Hasil ini berarti bahwa semakin baik dan tepat dalam menerapkan strategi pelayanan guru sekolah minggu, maka akan mampu meningkatkan kerohanian anak sekolah minggu di GKII Kecamatan Kongbeng dan Kecamatan Telen menjadi semakin bertumbuh.

Untuk mengetahui bentuk strategi pelayanan sekolah minggu yang paling dominan mempengaruhi pertumbuhan 
rohani anak di Gereja Kemah Injil Indonesia Rantau Panjang, maka dilakukan analisis Classification Tress yang hasilnya sebagai berikut:

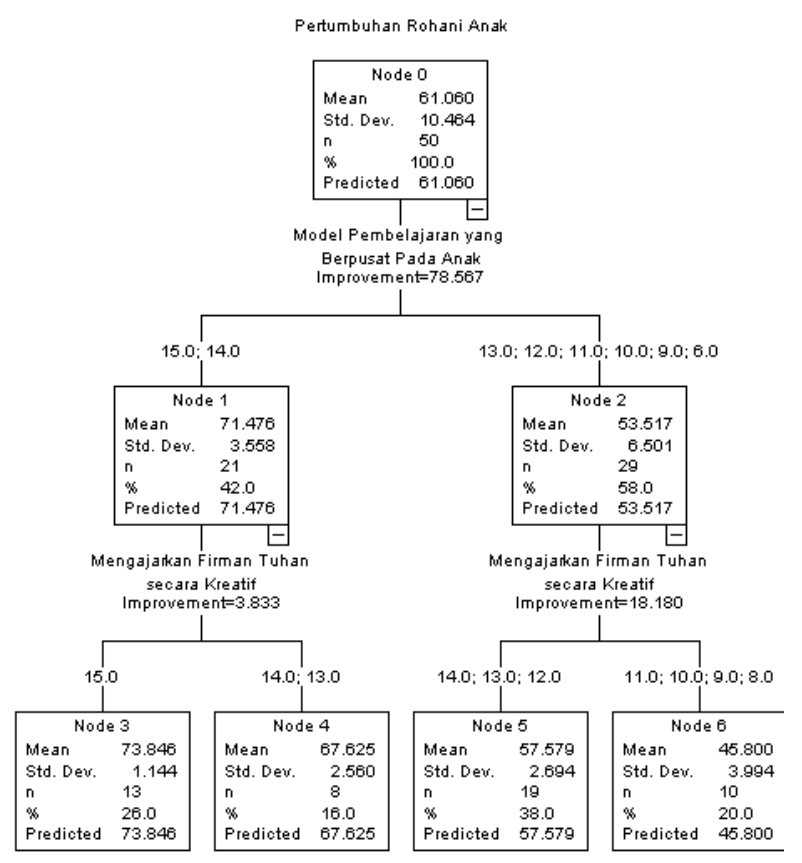

Gambar 1. Classification Tress

Berdasarkan hasil analisis pada gambar 1, menunjukkan bahwa strategi pelayanan sekolah minggu yang paling dominan berpengaruh bagi pertumbuhan rohani anak sekolah minggu adalah model pembelajaran yang berpusat pada anak. Strategi ini mampu meningkatkan pertumbuhan rohani anak sebesar 78,587. Sedangkan strategi lainnya yang berpengaruh secara tidak langsung bagi pertumbuhan rohani anak sekolah minggu, yaitu mengajarkan Firman Tuhan secara kreatif sebesar 22,013 yang signifikan pada $\alpha<0,05$. Dengan demikian, strategi pembelajaran dengan menerapkan model pembelajaran yang berpusat pada anak paling dominan berpengaruh bagi pertumbuhan rohani anak sekolah minggu.

Hasil penelitian ini sejalan dengan pernyataan Lie (2003) bahwa dalam mendisain pelayanan sekolah harus berpusat pada anak. Melalui strtaegi dengan menerapkan model pembelajaran yang disesuaikan dengan kebutuhan anak, maka pembelajaran sekolah minggu akan menyenangkan bagi anak. Hal ini yang akan membuat anak menyukai kegiatan sekolah minggu yang ditandai dengan kesetiaan, memberikan perhatian dan terlibat secara aktif dalam pembelajaran di sekolah minggu. Pembelajaran yang demikian, membuat guru mudah membimbing dan menuntun anak-anak, sehingga pembelajaran ini akan membuat anak semakin mengenal Tuhan dan bertumbuh dalam kehidupan rohaninya (Naipospos, 1988).

Pembelajaran sekolah minggu yang kreatif akan menarik bagi anak-anak. Ketertarikan tersebutlah membuat anak menyukai dan menyenangi ibadah (Efata, 2001). Sekolah minggu yang demikian membuat anak-anak belajar Firman Tuhan dengan kesungguhan hati dalam ibadah sekolah minggu, seluruh rangkaian kegiatan sekolah minggu diikuti dengan baik, sehingga dirinya mengalami pertumbuhan dalam kehidupan rohaninya. 
Melalui penggunaan alat peraga menjadi strategi yang tepat bagi guru-guru untuk menarik perhatian anak (Kadarmanto, 2003). Penggunaan alat peraga membuat anak-anak lebih cepat menangkap cerita Firman Tuhan karena ada yang dilihat atau dipandangnya, yang membuat anak-anak lebih besar dalam memberikan perhatiannya pada cerita Firman Tuhan tersebut. Menurut Blattner (2003) bahwa melalui pembelajaran yang membuat bahan pembelajaran seperti penggunaan alat peraga yang dapat dilihat oleh anak, mampu membuat pembelajaran menjadi efektif. Karena lebih dari 50\% materi pelajaran dapat diserap atau diingat anak-anak dengan baik. Sebaliknya apabila hanya mengandalkan indera mendengar, dimana guru dalam mengajar tidak menggunakan alat peraga dalam strategi pelayanannya, maka hanya $10 \%$ yang dapat diingat oleh anak-anak. Dengan demikian, strategi pembelajaran yang berorientasi pada anak seperti penggunaan alat peraga dan model yang sesuai kebutuhan anak, akan membuat anak sekolah minggu dapat mengingat materi atau cerita Firman Tuhan, sehingga dirinya dapat bertumbuh dalam kehidupan rohani.

\section{KESIMPULAN}

Berdasarkan analisis data, maka disimpulkan bahwa strategi pelayanan guru sekolah minggu berperan dalam meningkatkan pertumbuhan rohani anak. Startegi pelayanan yang diterapkan guru sekolah minggu dengan menerapkan model pembelajaran yang berpusat pada anak, menggunakan alat peraga dan mengajarkan Firman Tuhan secara kreatif akan berdampak pada peningkatan pertumbuhan rohani anak. Melalui pembelajaran yang kreatif dan inovatif melalui penggunaan alat peraga membuat anak menyukai kegiatan pembelajaran di sekolah minggu. Anak-anak lebih mudah memahami cerita Firman Tuhan dan membuatnya dapat mengingat dengan baik, sehingga anakanak dapat mengimplementasikan Firman Tuhan dalam kehidupan sehari-hari.

Guru sekolah minggu hendaknya kreatif dan inovatif yang dalam pembelajaran dapat meningkatkan animo anak-anak mengikuti ibadah dengan seungguh-sungguh, sehingga cerita Firman Tuhan yang didengarkan dapat diserap dan dirinya bertumbuh dalam pengenalan akan Tuhan. Guru sekolah minggu tidak menggunakan satu model atau strategi yang monoton dalam setiap kesempatan mengajar, namun juga menerapkan berbagai strategi yang disesuaikan dengan kebutuhan anak-anak yang diajarnya.

Gereja Kemah Injil Indonesia di Kecamatan Kombeng dan Telen secara khusus dalam pelayanan Sekolah Minggu, harapannya bisa mengimplementasikan hasil penelitian ini dan meningkatkan 
pelayanannya di bidang anak-anak, dalam rangka mempersiapkan generasi yang akan datang dalam kualitas hidup rohani yang baik, iman yang kokoh dan mampu menghadapi tantangan kemajuan zaman.

\section{DAFTAR PUSTAKA}

Blattner, D. (2003). Metode Mengajar Anak-anak Sekolah Minggu. Bandung: Lembaga Literatur Baptis.

Caram, P. G. (1996). Kekristenan Sejati. Jakarta: Nafiri Gabriel.

Christiani, T. K. (2003). Pendidikan Anak: Penting Tetapi Disepelekan. In Ajarlah Mereka Melakukan. Jakarta: BPK Gunung Mulia.

Efata, T. P. (2001). 80 Aktivitas Kreatif untuk Sekolah Minggu \& Persekutuan Remaja Pemuda. Yogyakarta: Andi Offset.

Griffiths, M. (1991). Gereja dan Panggilannya Dewasa ini. Jakarta: BPK Gunung Mulia.

Jacobsen, M. B. (1997). Ketika Anak Anda Bertumbuh. Bandung: Kalam Hidup.

Juanda. (2016). Pengaruh Kelas Pendalaman Iman Anak Lebak Arum (PIALA) terhadap Pertumbuhan Rohani Anak Usia 11-14 Tahun Di Kompleks Perumahan Lebak Arum Surabaya. Kerusso, 1(1), 51-56.

Kadarmanto, R. S. (2003). Tuntunlah ke Jalan yang Benar. Jakarta: BPK Gunung Mulia.
Kristiono, T., \& Perdana, D. P. (2019). Hambatan Guru dan Pelayanan Sekolah Minggu di Gereja Kristen Jawa Jebres Surakarta. Jurnal Teologi Gracia Deo, 1(2), 90-100. https://doi.org/10.46929/graciadeo.v1 i2.9

Latif, H. F. (2018). Pengaruh Pengajaran dan Persekutuan Terhadap Tingkat Pertumbuhan Rohani Anak dan Remaja. EPIGRAPHE: Jurnal Teologi Dan Pelayanan Kristiani, 1(2), 119. https://doi.org/10.33991/epigraphe.v1 i2.18

Laufer, R., \& Dyck, A. (1997). Pedoman Pelayanan Anak Seri 2. Malang: YPPII - Departemen Pembinaan Anak dan Pemuda.

Lie, P. (1997). Mengajar Sekolah Minggu yang Kreatif. Yogyakarta: Andi Offset.

Lie, P. (1999). Teknik Kreatif dan Terpadu dalam Mengajar Sekolah Minggu. Yogyakarta: Andi Offset.

Lie, P. (2003). Mereformasi Sekolah Minggu. Yogyakarta: Andi Offset.

Naipospos, P. S. (1988). Penuntun Sekolah Minggu. Jakarta: Yayasan Komunikasi Bina Kasih/OMF.

Nelly, N. (2019). Menerapkan Kesabaran Menurut Kitab Amsal dalam Mengajar Sekolah Minggu. KHARISMATA: Jurnal Teologi Pantekosta, 2(1), 20- 
27.

https://doi.org/10.47167/kharis.v2i1.2 6

Panuntun, D. F., Tanduklangi, R., Adeng, M., \& Randalele, C. E. (2019). Model Ibadah Sekolah Minggu KreatifInteraktif bagi Generasi Alfa di Gereja Toraja. BIA': Jurnal Teologi Dan Pendidikan Kristen Kontekstual, 2(2), 193-208.

https://doi.org/10.34307/b.v2i2.113

Purba, J. W. (2019). Peran Orangtua Dan Guru Pak Dalam Pembentukan Karakter Rohani Anak Di SDN Cawang 01 Pagi, Jakarta Timur. Institutio : Jurnal Pendidikan Agama Kristen, V(I), 1-8.

Retnaningsih, D. (2019). Tantangan dan Strategi Guru di Era Revolusi Industri 4.0 dalam Meningkatkan Kualitas Pendidikan. Prosiding Seminar Nasional: Kebijakan Dan Pengembangan Pendidikan Di Era Revolusi Industri 4.0., 21(September), 23-30.

Riniwati, R. (2020). Pembinaan Guru Sekolah Minggu Untuk Mengajarkan Konsep Keselamatan Pada Anak. Evangelikal: Jurnal Teologi Injili Dan Pembinaan Warga Jemaat, 4(2), 185. https://doi.org/10.46445/ejti.v4i2.247 Setiawani, M. G. (2000). Pembaharuan Mengajar. Bandung: Kalam Hidup.

Sidjabat, B. S. (2017). Mengajar secara
Profesional. Bandung: Kalam Hidup. Siswanto, I. (2006). 20 Peraga Sekolah Minggu Asyik. Yogyakarta: Andi Offset.

Widiyanto, M. A. (2013). Statistika Terapan. Konsep dan Aplikasi dalam Penelitian Bidang Pendidikan, Psikologi dan Ilmu Sosial Lainnya. Jakarta: PT Elex Media Komputindo. Widiyanto, M. A. (2014). Statistika Untuk Penelitian Bidang Teologi, Pendidikan Agama Kristen, \& Pelayanan Gereja. Bandung: Kalam Hidup. 